\title{
Myelomatous Ascites : A case report and Review of the Literature
}

\author{
Lemfadli $\mathrm{Y}^{1 *}$, Jiddi $\mathrm{S}^{1}$, Ait Errami $\mathrm{A}^{1}$, Samlani $\mathrm{Z}^{1}$, Oubaha $\mathrm{S}^{2}$ and Krati $\mathrm{K}^{1}$ \\ ${ }^{1}$ Department of Physiology, Cadi Ayyad University, Morocco \\ ${ }^{2}$ Department of Gastroenterology, Mohammed VI University Hospital, Morocco
}

Submission:November 09, 2019; Published: December 17, 2019

*Corresponding author: Lemfadli Y, Department of Physiology, Faculty of Medicine and Pharmacy at Cadi Ayyad University, Marrakech, Morocco

Abstract

Multiple myeloma (MM) is a hematological malignancy. Classically discovered during bone, hematological or renal manifestations. Myelomatous ascites is a rare extra-medullary manifestation associated with poor prognosis. We report a case of MM revealed by ascites as an initial manifestation of extramedullary involvement in a 56-year-old patient.

Keywords: Multiple myeloma; Hematological malignancy; Myelomatous; Etiological

\section{Introduction}

Multiple myeloma (MM), or plasma cell myeloma, is characterized by plasmocytic proliferation and the production of a large amount of specific immunoglobulins. The diagnosis is classically discovered on the occasion of bone, hematological or renal manifestations. Visceral disorders are rare and usually seen at an advanced stage [1]. We report a case of MM revealed by ascites secondary to peritoneal involvement in the context of extramedullary localization.

\section{Case Report}

A 56-year-old lady was admitted to our department for an etiological assessment of an oedemato-ascitic syndrome. During the interview, the patient had a history of chronic renal insufficiency undergoing hemodialysis for 2 years $(2$ sessions per week).

During the general clinical examination, there was an alteration of the general state of health with asthenia and a loss of weight, without fever. A BMI at $17.2 \mathrm{~kg} / \mathrm{m}^{2}$ and a WHO score at 2 There was pitting edema of the lower limbs, bilateral. Examination of the abdomen revealed a diffuse sensitivity, with ascites of great abundance associated with homogeneous hepatomegaly, painless (hepatic arrow at $18 \mathrm{~cm}$ ). The remainder of the examination was normal including cardiovascular examination, without clinical signs of portal hypertension or hepatocellular insufficiency. The ganglionic areas were free.

A morphological assessment based on an abdominopelvic CT scan confirmed the existence of homogeneous ascites and hepatomegaly without evidence of portal hypertension or ovarian mass.

The exploratory puncture of the ascites fluid found a fluid poor in non-superinfected protein according to the following formula (protein content at $22 \mathrm{~g} / \mathrm{L}$ with albumin level at $11.9 \mathrm{~g} / \mathrm{l}$ ) with leucocytes at 50elements $/ \mathrm{mm}^{3}, 10 \%$ were neutrophils and $90 \%$ lymphocytes with 350 cells $/ \mathrm{mm}^{3}$ cells. The direct examination did not isolate the germ with a sterile culture at 48 hours.

The other biological data were as follows: normocytic normochromic anemia at $9.3 / \mathrm{dL}$, with reticulocyte level at 52.700/ $\mathrm{mm}^{3}$, thrombocytopenia at $94000 / \mathrm{mm}^{3}$ without leukocytosis or leukopenia. The transaminase activity was normal and anicteric cholestasis was noted: GGT at 113IU/l, alkaline phosphatase at $229 \mathrm{IU} / \mathrm{l}$, with total bilirubin at $7.6 \mu \mathrm{mol} / \mathrm{L}$. The prothrombin rate was $63 \%$ and the factor $\mathrm{V} 85 \%$.

A protein level of $64 \mathrm{~g} / \mathrm{L}$ was also noted with $32 \mathrm{~g} / \mathrm{L}$ albuminemia. Electrophoresis of plasma proteins showed monoclonal gammopathy. Immunofixation of serum proteins showed kappa light chain IgA monoclonal immunoglobulin. The 24-hour proteinuria was negative. The viral serologies B, C were negative.

The initial diagnostic hypothesis of ascites complicating chronic liver disease was quickly ruled out due to the absence of hepatic insufficiency and portal hypertension.

The myelogram was inconclusive. A bone marrow biopsy showed diffuse medullary infiltration by plasma cells with the 
presence of $20 \%$ dystrophic plasma cells (Figure 1). The diagnosis of MM with peritoneal involvement was made. The patient was

transferred to the hematology department for specialized management (Figure 2).

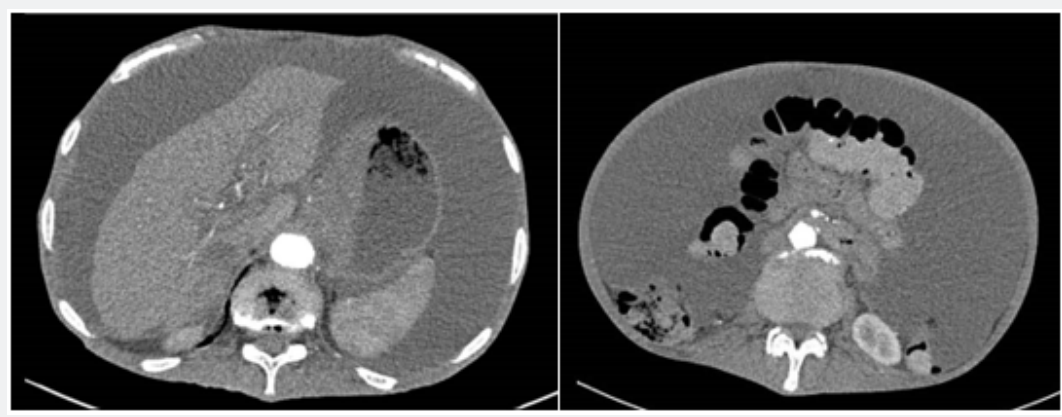

Figure 1: Scanner of our patient who shows peritoneal infiltration with ascites of great abundance.

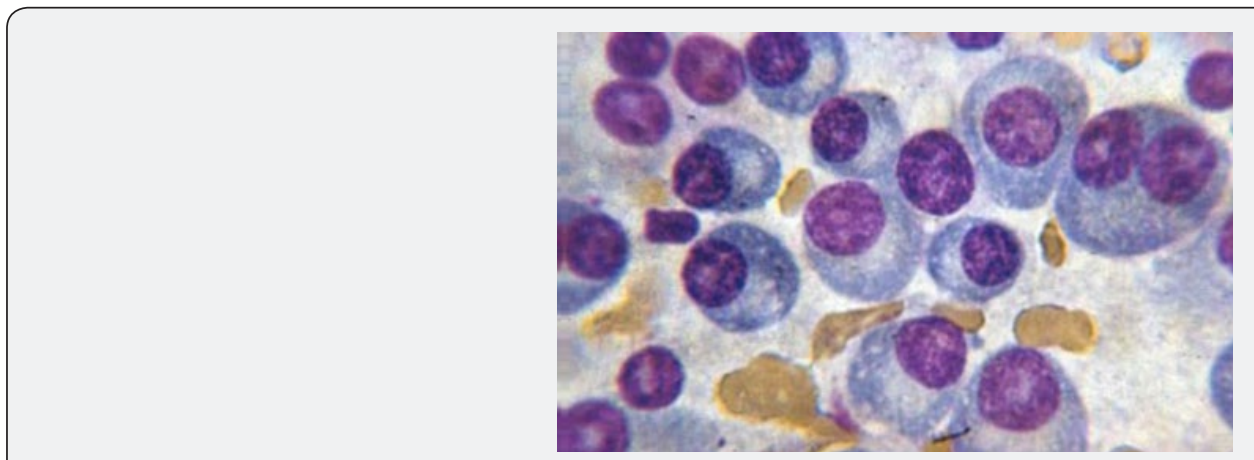

Figure 2: Histopathological section of bone marrow biopsy of our patient showing medullary infiltration by binucleated plasmocytes.

\section{Discussion}

Approximately $70 \%$ of patients with plasmocytic tumors have extramedullary tumor infiltration [2]. The most common extramedullary involvement is the upper respiratory tract and the liver. The appearance of ascites in patients with myeloma is usually secondary to significant hepatic infiltration by plasma cells. It may also be secondary to heart failure, kidney damage or infectious peritonitis. In contrast, myeloma ascites caused by peritoneal infiltration of tumor cells are very rare as the case of our patient. They can inaugurate clinical manifestations or develop during the evolution of the disease $[1,3]$.

The clinical cases of myelomatous ascites and pleural effusion reported in the literature are generally associated with a poor prognosis [4,5]. Karp and Shareef reported that median survival was 1.5 months in 9 patients with myelomatous ascites [3]. However, several cases of improvement under treatment with prolonged survival have been reported hence the interest of early diagnosis [6,7].

The IgA isotype represents a quarter of MM cases. $62.5 \%$ of patients with Myelomatous ascites have IgA isotype myeloma [1]. Higher levels of plasma IgA are associated with extramedullary effects. Lake et al. [8] hypothesized that the cause was higher IgA production by lymphoid cells in multiple myeloma, which may disproportionately affect extramedullary sites.

\section{Conclusion}

The diagnosis of MM is possible even in the absence of bone involvement or haematological or renal complications. These modes of extra-medullary revelation are rare and have poor prognosis.

\section{References}

1. Choi SY, Lee HK, Yi BH, Lee MH, Kim HK, et al. (2017) Myelomatous Ascites as an Initial Manifestation of Extramedullary Involvement of Multiple Myeloma. J Korean Soc Radiol 76(3): 187-190.

2. Shimizu M, Tsurumi H, Hara T, Fukutomi Y, Moriwaki H (1999) Multiple myeloma presenting as massive ascites. Rinsho Ketsueki 40: 515-517.

3. Karp SJ, Shareef D (1987) Ascites as a presenting feature multiple myeloma. J R Soc Med 80(3): 182-184

4. Greer JP, Pinson RD, Russell WG, Keith TA, Collins RD, et al. (1985) Malignant plasmacytic ascites. A report of two cases and a review of the literature. Cancer 56(8): 2001-2004.

5. Ohmoto A, Kohno M, Yasukawa K, Matsuyama R (1996) Massive ascites as an initial sign, plasmacytoma of the cervical supine, and hyperammonemic consciousness disturbance in a patient with biclonal type multiple myeloma. Rinsho Ketsueki 37(4): 346-351. 
6. Jackson SR, Hawkins TE, Green GJ, Carter JM, Romeril KR (1992) Plasmacytic ascites responsive to multiagent chemotherapy. Am J Hematol 41(4): 298.

7. Alegre A, Martínez-Chamorro C, Fernández-Rañada JM (1999) Massive myelomatous ascites responsive to VAD chemotherapy and autologous stem cell transplantation. Bone Marrow Transplant 24(3): 343-344.

8. Lake G, Schade RR, Van Thiel DH (1983) Extrahepatic biliary tract obstruction due to plasmacytoma. J Clin Gastroenterol 5(3): 273-276.

\section{Your next submission with Juniper Publishers} will reach you the below assets

- Quality Editorial service

- Swift Peer Review

- Reprints availability

- E-prints Service

- Manuscript Podcast for convenient understanding

- Global attainment for your research

- Manuscript accessibility in different formats

( Pdf, E-pub, Full Text, Audio)

- Unceasing customer service

Track the below URL for one-step submission https://juniperpublishers.com/online-submission.php 